\title{
Depositional Controls on the Quality of Clastic Reservoirs: A Review
}

\author{
Oladapo Akinlotan \\ Department of Geography, University of Sussex, Brighton, United Kingdom
}

Email address:

o.akinlotan@sussex.ac.uk,dapo_akinlotan@yahoo.com

To cite this article:

Oladapo Akinlotan. Depositional Controls on the Quality of Clastic Reservoirs: A Review. Earth Sciences. Vol. 10, No. 3, 2021 , pp. 70-82. doi: 10.11648/j.earth.20211003.11

Received: February 18, 2021; Accepted: March 8, 2021; Published: May 27, 2021

\begin{abstract}
A comprehensive review of important data from eighty-one clastic reservoirs across the world has yielded important conclusions on the relationship between the depositional environments and clastic reservoir quality. High porosity and permeability have significant controls on the amount of hydrocarbon recoverable in clastic reservoirs, but they may not necessarily guarantee the highest possible recoverable. Permeability can vary very significantly with the same porosity and sometimes the highest permeability does not necessarily occur with the highest porosity. There is a drastic reduction in porosity at depth greater than $3450 \mathrm{~m}$ regardless of the depositional environment. Gas reservoirs have tendency to recover higher amount of hydrocarbon at relatively lower porosity and permeability when compared to oil reservoirs. The present review suggests that an oil reservoir with porosity of about $20 \%$ and a permeability of around $1100 \mathrm{mD}$ may recover about $43.6 \%$ of oil in place provided all other necessary geologic factors are in place. Gas reservoirs are likely to recover more than $43.6 \%$ with similar or lower porosity and permeability. This review will serve as a useful guide to petroleum geologists and sedimentologists in understanding the quality of clastic reservoirs in different environments.
\end{abstract}

Keywords: Clastic Reservoirs, Porosity, Permeability, Hydrocarbon, Depositional Environments

\section{Introduction}

Depositional environments exert significant controls on the quality of clastic reservoirs and have significant influence on many factors including overall architecture, geometry, heterogeneity, facies, grain composition and size, sorting, pay thickness, and net to gross of reservoirs $[1-3,51,54,62,67]$. These factors in turn control porosity, permeability, and the amount of hydrocarbon recoverable in sandstone reservoirs. Porosity and permeability exert substantial controls on the quality of hydrocarbon reservoirs [11, 12, 54] because they define the amount of hydrocarbon that can be recovered from any reservoir $[13,45]$ The quality of clastic hydrocarbon reservoirs is of great economic importance because this determines the amount of hydrocarbons that can be recovered at any given time.

The aim of this paper is to review the relationship between depositional environments and the quality of clastic reservoirs and examine the influence and controls of depositional environments on the quality of clastic reservoirs. This relationship will be useful to petroleum geologists and sedimentologists in predicting and understanding the quality of clastic reservoirs in different depositional environments.

\section{Methodology}

In this review, important reservoir data from over eighty clastic reservoirs across major depositional environments are reviewed. The reservoir data include porosity, permeability, depth, pay thickness, net to gross, area, hydrocarbon type, hydrocarbon in place and recoverable, depositional environment, stratigraphic unit and age, name of field, basin, and the country of location and are presented in Tables 1-6. The data were sourced from the literature and analysed using Microsoft Excel spreadsheet. Additional details including the depositional environments and the measurements details on the reservoir analysed are available in their original sources, which are available in the reference list.

\section{Results and Interpretations}

\subsection{Fluvial Reservoirs}

From thirty-two fluvial reservoirs (Table 1), the average 
porosity is $19.4 \%$. The relationship between porosity and depth is not straightforward (Figure 1a). The highest porosity (35\%) occurs at a depth of $152 \mathrm{~m}$ while the third highest porosity of $29 \%$ occurs at a depth of $2779 \mathrm{~m}$. On the other hand, the second lowest porosity of $10 \%$ occurs at a depth of $2195 \mathrm{~m}$ while the deepest reservoir at the depth of $3450 \mathrm{~m}$ has porosity of $21.5 \%$ which is higher than the average porosity. About $85.7 \%$ of the data points plots within porosity range of 15 and $29 \%$ while $78.5 \%$ plots within 15 and $24 \%$. These porosity values point to an important range for the average porosity in fluvial reservoirs. This porosity range of 15 and $29 \%$ may also have other important implications for clastic reservoirs. The reservoir with the highest porosity of $35 \%$ occurs at a shallow depth of $152 \mathrm{~m}$ and is located in an onshore field. Many factors may be responsible for this high porosity. The shallow depth of the reservoir may be an important factor, which may also facilitate a negligible diagenetic destruction of the primary porosity.

Table 1. Details of fluvial reservoirs. Abbreviations for Tables 1-5: L: Lower, M: Middle, U: Upper, E: Early, Lt: Late, Cam: Cambrian, Sil: Silurian, Dev: Devonian, Carb: Carboniferous, Per: Permian, Tr: Triassic, Ju: Jurassic, Cr: Cretaceous, Pal: Palaeocene, Eo: Eocene Olig: Oligocene, Mio: Miocene, Pli: Pliocene, Ple: Pleistocene, Ss: Sandstone, O: Oil, G: Gas. MMBO: Million Barrels of Oil, BCFG: Billion Cubic Feet Gas. Average values in brackets.

\begin{tabular}{|c|c|c|c|c|c|}
\hline Field & Basin & Location & Strat Unit & Age & Depositional Environment \\
\hline Messla & Sirte & Libya & Sarir Ss & L. $\mathrm{Cr}$ & Stacked braided channels \\
\hline McArthur River & & USA & Hemlock Ss- & Olig & Alluvial-fluvial \\
\hline \multirow[t]{2}{*}{ October } & & Egypt & Nubia Ss & Carb-Cr & Stacked fluvial channels, \\
\hline & & & & & blanket sandstone \\
\hline Hassi Messaoud & & Algeria & $\mathrm{RaSs}$ & Cam & Blanket sandstone \\
\hline Brent & & UK & Statfjord & U. Tr- L. Ju & Braided/meandering \\
\hline \multirow[t]{2}{*}{ Buchan } & & UK & Old Red & Dev-Carb & Braided \\
\hline & & & Sandstone & & \\
\hline Caister B & & UK & Bunter Ss & $\operatorname{Tr}$ & Channel/sheet flood \\
\hline Caister C & & UK & Coal Measures & Carb & Braided/low sinuosity \\
\hline Esmond Complex & & UK & Bunter Ss & $\operatorname{Tr}$ & Braided/alluvial fan \\
\hline Heidrum & & Norway & Garn & M. Ju & Braided/meandering \\
\hline Hewett & & UK & Bunter Ss & $\operatorname{Tr}$ & Alluvial plain \\
\hline Morecambe & & UK & Sherwood Ss & $\operatorname{Tr}$ & Braided \\
\hline Snorre & & Norway & Lunde Ss & L. Tr & Braided channels \\
\hline Snorre & & Norway & Statfjord & L. Tr & Braided/low sinuosity \\
\hline Statfjord & & UK/Norway & Statfjord & U. Tr-L. Ju & Braided/meandering? \\
\hline Azal & & Yemen & Alif & $\mathrm{Cr}$ & Braidplain/channel fill \\
\hline Bu Attifel & & Libya & Sarir Ss & L. $\mathrm{Cr}$ & Braided \\
\hline North Rankin & & Australia & & Tr- L. Ju & Braided \\
\hline Peco & Western Interior & Canada & Belly River & L. $\mathrm{Cr}$ & Braided/ single channel \\
\hline Prudhoe Bay & Colville Trough & Alaska & Ivishak Ss & Per-Tr & Braided, fluvio-deltaic \\
\hline South Belridge & San Joaquin Valley & USA & Tulare & Ple & Braided, fluvio-deltaic \\
\hline Ninian & & UK & Brent & $\mathrm{Ju}$ & Fluvio-deltaic \\
\hline \multirow[t]{2}{*}{ Tiajuana } & & Venezuela & Misoa Ss & Eo & Fluvio-deltaic \\
\hline & Gulf of Mexico & USA & Wilcox & Pal- Eo & Fluvio-deltaic \\
\hline Weixing & Songliao & NE China & Putaohua & L. $\mathrm{Cr}$ & Fluvio-deltaic \\
\hline Main Consolidated & Illinois & USA & Caseyville & L. Carb & Fluvio-estuarine \\
\hline Sarir C-Main & & Libya & Sarir Ss & L. $\mathrm{Cr}$ & Braided \\
\hline Vacas Muertas & & Argentina & Barancas & $\mathrm{Cr}$ & Alluvial fan \\
\hline Rocky Ridge & Williston & USA & Tyler & L. Carb & Meander belt \\
\hline \multirow[t]{2}{*}{ Little Creek } & Mississippi Salt & USA & Lower & L. $\mathrm{Cr}$ & Meander belt \\
\hline & & & Tuscaloosa & & \\
\hline Greater Burgan & & Kuwait & Burgan & L. $\mathrm{Cr}$ & Fluvial and tidal dominated \\
\hline Crawford & & UK & & $\mathrm{Tr}-\mathrm{Cr}$ & Fluvial channel fills \\
\hline Wytch Farm & & UK & Sherwood Ss & $\operatorname{Tr}$ & Braided \\
\hline Barryroe & Celtic Sea & Ireland & Wealden & L. $\mathrm{Cr}$ & Fluvial? \\
\hline Crystal & Western Interior & Canada & Viking & E. $\mathrm{Cr}$ & Estuary \\
\hline Senlac & Western Canada & Canada & Lloydminster/ Mannville & E. $\mathrm{Cr}$ & Estuary \\
\hline
\end{tabular}

Table 1. Continued.

\begin{tabular}{|c|c|c|c|c|c|c|c|c|c|}
\hline $\begin{array}{l}\text { Depth } \\
\text { (m) }\end{array}$ & $\begin{array}{l}\text { Porosity } \\
(\%)\end{array}$ & $\begin{array}{l}\text { Permeability } \\
(\mathrm{mD})\end{array}$ & $\begin{array}{l}\text { Thickness of } \\
\text { Pay (m) }\end{array}$ & $\begin{array}{l}\text { Net/Gross } \\
(\%)\end{array}$ & $\begin{array}{l}\text { Area } \\
(\mathrm{Sq} \mathrm{Km})\end{array}$ & Type & $\begin{array}{l}\text { In Place } \\
\text { (MMBO/BCFG) }\end{array}$ & $\begin{array}{l}\text { Recoverable } \\
\text { (MMBO/ BCFG }\end{array}$ & References \\
\hline 2644 & 17 & 500 & 300 & & 230 & $\mathrm{O}$ & 3000 & $\begin{array}{l}1000-1500 \\
(33-50 \%)\end{array}$ & Clifford et al. [18] \\
\hline 2560 & 17 & 80 & & & & $\mathrm{O}$ & 570 & & Morse [54] \\
\hline
\end{tabular}




\begin{tabular}{|c|c|c|c|c|c|c|c|c|c|}
\hline $\begin{array}{l}\text { Depth } \\
\text { (m) }\end{array}$ & $\begin{array}{l}\text { Porosity } \\
(\%)\end{array}$ & $\begin{array}{l}\text { Permeability } \\
\text { (mD) }\end{array}$ & $\begin{array}{l}\text { Thickness of } \\
\text { Pay (m) }\end{array}$ & $\begin{array}{l}\text { Net/Gross } \\
(\%)\end{array}$ & \multicolumn{2}{|c|}{$\begin{array}{l}\text { Area } \quad \text { Type } \\
\text { (Sq Km) }\end{array}$} & \multirow[t]{2}{*}{$\begin{array}{l}\text { In Place } \\
\text { (MMBO/BCFG) }\end{array}$} & $\begin{array}{l}\text { Recoverable } \\
\text { (MMBO/ BCFG }\end{array}$ & $\begin{array}{l}\text { References } \\
\text { G) }\end{array}$ \\
\hline 3350 & 17 & 236 & 135 & & & & & & Lelek et al. [42] \\
\hline \multirow[t]{9}{*}{3350} & $2-12$ & & 120 & & & $\mathrm{O}$ & 25000 & $9000(36 \%)$ & Balducchi and Pommier [7] \\
\hline & $16-29$ & $20-10000$ & & $35-90$ & 39 & $\mathrm{G}, \mathrm{O}$ & $580 / 3241$ & $\begin{array}{l}313(54 \%) / 1215 \\
(37.5 \%)\end{array}$ & Martin [45] \\
\hline & $7-11$ & $0.1-2$ & & & 14 & $\mathrm{O}$ & 466 & $83.8(18 \%)$ & Martin [45] \\
\hline & $11-30$ & $1-1000$ & & $84-100$ & 7.5 & G & 156 & $75 \%$ & Ritchie and Pratsides [60] \\
\hline & $6-15$ & $0.1-400$ & & $67-80$ & 15 & G & 230 & $186.3(81 \%)$ & Ritchie and Pratsides [60] \\
\hline & $9-24$ & & & $70-95$ & 39 & G & & 533 & Ketter (38] \\
\hline & $27-35$ & 9000 & & & 40 & O.G & $1000 \mathrm{BCFG}$ & & Harris [28] \\
\hline & $19-23$ & $250-1000$ & & $88-98$ & 190 & G & & & Cooke-Yarborough (19] \\
\hline & $14-15$ & $1-100$ & & $56-85$ & 170 & G & 6750 & $5400(80 \%)$ & Bushell [14] \\
\hline \multirow[t]{6}{*}{2526} & $19-29$ & $320-535$ & & $35-68$ & 50 & $\mathrm{O}$ & $2080-3000$ & $\begin{array}{l}770-2,080 \\
(21-41 \%)\end{array}$ & Martin [45], Morse [54] \\
\hline & $19-29$ & $1300-2000$ & & $4-6.3$ & 30 & $\mathrm{O}$ & 2,080 & $\begin{array}{l}665.6-873.6 \\
(32-42 \%)\end{array}$ & Martin [45] \\
\hline & $18-23$ & 1500 & & $50-72$ & 35 & $\mathrm{O}$ & 1,500 & $630(42 \%)$ & Morse [54] \\
\hline & $16-18$ & $500-1200$ & & & 13 & $\mathrm{O}, \mathrm{G}$ & & $142 / 5.7$ & Huurdeman et al. [34] \\
\hline & $8-16$ & $1-1000$ & & & 55 & $\mathrm{O}$ & & $15 \%$ & Martin [45] \\
\hline & $17-21$ & $500-1500$ & & $75-83$ & 50 & G & & 7700 & Martin [45] \\
\hline 2195 & $6-13(10)$ & $1-150(5)$ & 5.5 & 30 & 91.2 & $\mathrm{O}, \mathrm{G}$ & 34 & $3.4(10 \%)$ & Gardiner et al. [24] \\
\hline $2440-2800$ & $10-30(22)$ & $20-4000(400)$ & $148-174$ & 87 & 1140 & $\mathrm{O}, \mathrm{G}$ & $21500 / 46,500$ & $12040(56 \%)$ & Atkinson et al. [5] \\
\hline 152 & $32-42(35)$ & $\begin{array}{l}100-10000 \\
(3000)\end{array}$ & $15-84$ & $30-70$ & 51.2 & $\mathrm{O}$ & & 1,200 & Miller et al. [52] \\
\hline 2779 & 29 & 1000 & 110 & & & $\mathrm{O}$ & & 1,200 & Albright et al. [4] \\
\hline $750-4850$ & $12-28$ & 240 & & & & $\mathrm{O}$ & & 5,000 & Talukdar and Marcano [68] \\
\hline $200-6700$ & $10-33$ & $0.08-185$ & & & & $\mathrm{O}, \mathrm{G}$ & & & Dutton and Loucks [21] \\
\hline $1150-1490$ & $15-26$ & $0.01-400$ & & & & $\mathrm{O}, \mathrm{G}$ & & & Sun et al. [67] \\
\hline \multirow[t]{3}{*}{380} & $6-25(15)$ & $0-3570(670)$ & 5.8 & 40 & 2.56 & $\mathrm{O}, \mathrm{G}$ & 4.6 MMBO & $1.5(33 \%)$ & Howard and Whitaker [33] \\
\hline & $13-17$ & $30-600$ & & $50-95$ & 800 & $\mathrm{O}$ & 8000 & $2000(25 \%)$ & Martin [45] \\
\hline & 17.5 & 217 & & & & $\mathrm{O}$ & 400 & $38.5(9.6 \%)$ & Martin [45] \\
\hline 2470 & $13-25(16)$ & $60-780(115)$ & 7.6 & 83 & 20.8 & $\mathrm{O}$ & 11.4 & $3.4(30 \%)$ & Hastings [29] \\
\hline \multirow[t]{5}{*}{3283} & $10-35(24)$ & $0.1-1000(100)$ & 9.1 & 75 & 46.6 & $\mathrm{O}$ & 102 & $68(67 \%)$ & Werren et al. [70] \\
\hline & $19-25$ & $10-1600$ & 380 & & & $\mathrm{O}$ & & $>10000$ & Strohmenger et al. [65] \\
\hline & $20-25$ & $10-2500$ & $7-181$ & $30-50$ & & $\mathrm{O}$ & $130-1000$ & $9(6.9 \%)$ & Gluyas and Swarbrick [25] \\
\hline & $5-30$ & $0.01-1000$ & & & 34 & $\mathrm{O}$ & 350 & & Martin [45] \\
\hline & 16 & 50 & & & & & & & Gluyas and Swarbrick [25] \\
\hline 100 & 15 & $100-600$ & 12.5 & & & $\mathrm{O}, \mathrm{G}$ & $\begin{array}{l}1043-1612 \\
\text { MMBO }\end{array}$ & $\begin{array}{l}300 \\
(18.6-28.7 \%)\end{array}$ & Providence [57] \\
\hline 1750 & $6-25(10.5)$ & $0.01-2500(200)$ & $3-30.5$ & 95 & 92.8 & $\mathrm{O}$ & 102 & $34.6(34 \%)$ & Clark and Reinson [16] \\
\hline $775-805$ & $\begin{array}{l}25-31 \\
(27.5-30)\end{array}$ & $\begin{array}{l}2500-4000 \\
(2500-3000)\end{array}$ & $3-7$ & 100 & 17.9 & $\mathrm{O}$ & 84.37 & $6.4(7.5 \%)$ & Zaitlin and Shultz [71] \\
\hline 1750 & $6-25(10.5)$ & $0.01-2500(200)$ & $3-30.5$ & 95 & 92.8 & $\mathrm{O}$ & 102 & $34.6(34 \%)$ & Clark and Reinson [16] \\
\hline $775-805$ & $\begin{array}{l}25-31 \\
(27.5-30) \\
\end{array}$ & $\begin{array}{l}2500-4000 \\
(2500-3000)\end{array}$ & $3-7$ & 100 & 17.9 & $\mathrm{O}$ & 84.37 & $6.4(7.5 \%)$ & Zaitlin and Shultz [71] \\
\hline
\end{tabular}

Table 2. Details of deltaic reservoirs.

\begin{tabular}{|c|c|c|c|c|}
\hline Field Basin & Location & Strat Unit & Age & Depositional Environment \\
\hline Senecaville Appalachian & USA & Clinton & E. Sil & Deltaic \\
\hline Cano Limon Llanos & Colombia & Mirador Ss, Carbonera & Lt. Cr-Oli & River-dominated deltaic, stacked channels, shallow marine \\
\hline Northwest Hutton/East Shetland & UK & Brent & M. Ju & Shallow marine/ fluvio-deltaic \\
\hline Burgan & Kuwait & Wasia & $\mathrm{Cr}$ & Deltaic and shallow shelf \\
\hline Safaniya & Saudi Arabia & Khafji & U. $\mathrm{Cr}$ & Stacked delta plain, mouth bar and bay fill \\
\hline Hibernia & Canada & Hibernia & U. Ju & Delta plain, straight channel, fluvial delta \\
\hline Badak & Indonesia & Balikpapan & Mio-Pli & Stacked delta plain, channel, mouth bar and delta front \\
\hline Bekapai & Indonesia & Balikpapan & Mio-Pli & Stacked delta plain, channel, mouth bar and delta front \\
\hline Oseberg & Norway & Oseberg Ness & & Delta lobes stacked with delta plain \\
\hline Smorbukk & Norway & Tilje, Iie, Garn & & Tidal influence shoreline and braided delta complex \\
\hline Statfjord & UK/Norway & Brent and Statfjord & $\mathrm{Ju}$ & Delta front, mouth bar and channels \\
\hline Cambay-Hazard (!) & India & Hazad & M. Mio & Prograding deltaic Sandstone \\
\hline Prudhoe Bay & USA & Sadlerochit & L. Tr & Deltaic, fluvial \\
\hline Island Block 300 & Gulf of Mexico & & Pli-Ple & Delta front Sandstone on marine shelf \\
\hline Medora/Williston & USA & Tyler & L. Carb & Barrier Island \\
\hline
\end{tabular}


Table 2. Continued.

\begin{tabular}{|c|c|c|c|c|c|c|c|c|c|}
\hline \multirow{2}{*}{$\begin{array}{l}\text { Depth } \\
\text { (m) }\end{array}$} & \multirow{2}{*}{$\begin{array}{l}\text { Porosity } \\
\text { (\%) }\end{array}$} & \multirow{2}{*}{$\begin{array}{l}\text { Permeability } \\
(\mathrm{mD})\end{array}$} & \multirow{2}{*}{$\begin{array}{l}\text { Thickness } \\
\text { of Pay (m) }\end{array}$} & \multirow{2}{*}{$\begin{array}{l}\text { Net/Gross } \\
(\%)\end{array}$} & Area & Type & \multirow{3}{*}{$\begin{array}{l}\text { In Place } \\
\text { (MMBO/BCFG } \\
\text { ( }\end{array}$} & \multirow{2}{*}{$\begin{array}{l}\text { Recoverable } \\
\text { (MMBO/BCFG } \\
\text { ) }\end{array}$} & \multirow[b]{2}{*}{ References } \\
\hline & & & & & $(\mathbf{S q} \mathbf{K m}$ & & & & \\
\hline 1710 & $2-16(8)$ & $0.01-5(0.5)$ & 18 & 32 & 7.7 & $\mathrm{G}, \mathrm{O}$ & & $4.2(60 \%)$ & Keltch et al. [37] \\
\hline $2286-2500$ & $12-32(25)$ & $\begin{array}{l}10.0-8000 \\
(1450)\end{array}$ & $65-150$ & $23-76$ & 60 & $\mathrm{O}$ & 1940 & $1050(54 \%)$ & $\begin{array}{l}\text { Cleveland and Molina } \\
{[17]}\end{array}$ \\
\hline 145 & $8-24(18)$ & $0.1-2000$ (99) & 55 & 45 & 48 & $\mathrm{O}, \mathrm{G}$ & $670 \mathrm{MMBO}$ & $200(30 \%)$ & $\begin{array}{l}\text { Scotman and Johnes } \\
{[61]}\end{array}$ \\
\hline $300-2500$ & $20-35$ & $250-8000$ & & & & $\mathrm{O}$ & & 66000 & Morse [54] \\
\hline 1500 & $20-35$ & $250-8000$ & & & & $\mathrm{O}$ & 88000 & $3230037 \%$ & Morse [54] \\
\hline 3720 & 16 & 500 & 68 & & & $\mathrm{O}$ & & 2000.1 & Morse [54] \\
\hline 1372 & 22 & 200 & & & & $\mathrm{G}, \mathrm{O}$ & & $3160 \mathrm{BCFG}$ & Morse [54] \\
\hline 1300 & $25-35$ & 1000 & & & & & & & Morse [54] \\
\hline $2120-2700$ & 24 & 2000 & & & & $\mathrm{O}, \mathrm{G}$ & 1420 & $\begin{array}{l}770 \mathrm{MMBO} \\
(51 \%)\end{array}$ & $\begin{array}{l}\text { Hagen and Kvalheim } \\
{[26]}\end{array}$ \\
\hline $3800-4400$ & 11 & $10-1000$ & & & & $\mathrm{O}, \mathrm{G}$ & 1180 & & Ehrenberg et al. [22] \\
\hline 2585 & 29 & $250-1500$ & 300 & & & $\mathrm{O}$ & 5600 & $3400(61 \%)$ & Kirk [39] \\
\hline 2750 & $12-22$ & 250 & & & & $\mathrm{O}$ & 2700 & & Biswas et al. [10] \\
\hline 2438 & 20 & 500 & & & & $\mathrm{O}, \mathrm{G}$ & & 14900 & Morse [54] \\
\hline $1290-3600$ & 30 & 1000 & 330 & & & & & 400 & Holland et al. [31] \\
\hline 2367 & $2-22(12)$ & $0.1-750(90)$ & 4.3 & 100 & 17.8 & $\mathrm{O}$ & 24.8 & $7.1(29 \%)$ & Barwis [8] \\
\hline
\end{tabular}

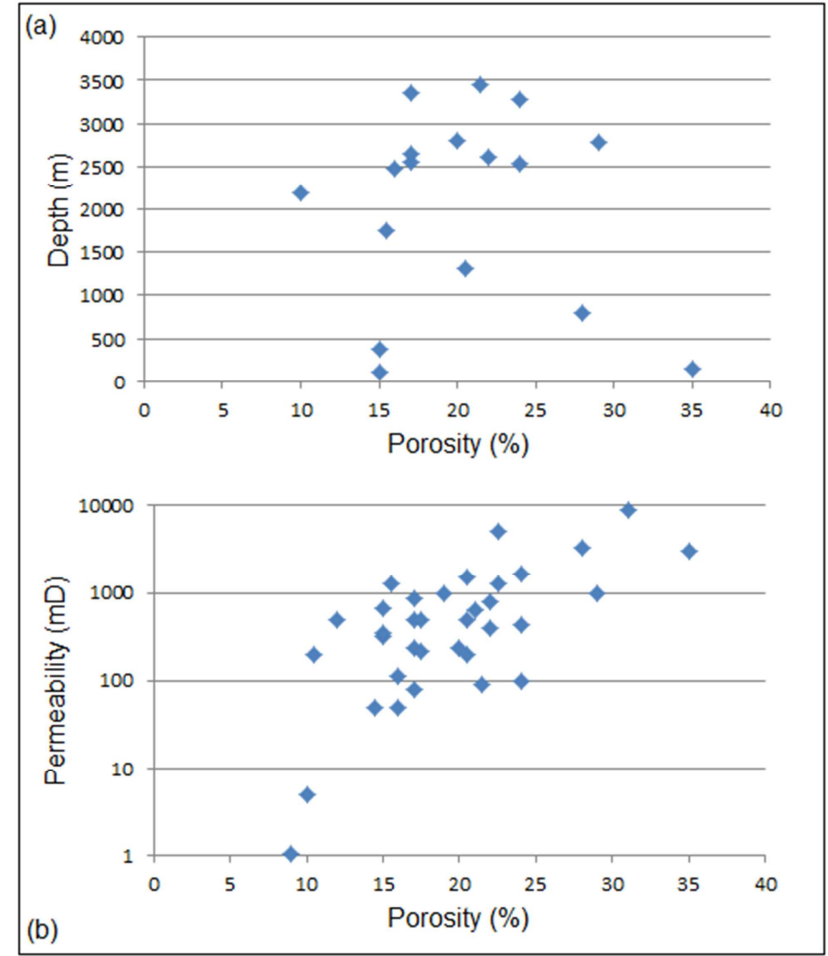

Figure 1. Key data from fluvial reservoirs.

Permeability generally increases with porosity although it sometimes varies significantly with similar porosity values (Figure $1 b$ ). With a porosity of $15 \%$, permeability ranges from 315 to $670 \mathrm{mD}$ while permeability varies from 80 to $850 \mathrm{mD}$ for porosity of $17 \%$. The average amount of hydrocarbon recoverable in these reservoirs is $40 \%$ and this generally increases with porosity and permeability. However, the top three recoverable values $(75,80$, and $81 \%$ ) occur with porosity of $20.5,14.5$ and $10.5 \%$ respectively. The three reservoirs with the highest recoverable of 81,80 and $75 \%$ are producing gas which demonstrates that gas has tendency for higher recovery than oil.

A large proportion of the porosity range between 15 and $29 \%$ are well represented above depth of $2195 \mathrm{~m}$ (Figure 1a). The amount of hydrocarbon also increases significantly well above this depth. Most of the fluvial reservoirs appear to have good quality above this depth and this may suggest a significant increase in the quality of fluvial reservoirs above $2100 \mathrm{~m}$. Apart from the reservoir with the lowest depth of $100 \mathrm{~m}$, recoverable generally increases with the average depth of reservoir $(2068 \mathrm{~m})$ in this environment (Figure 1a).

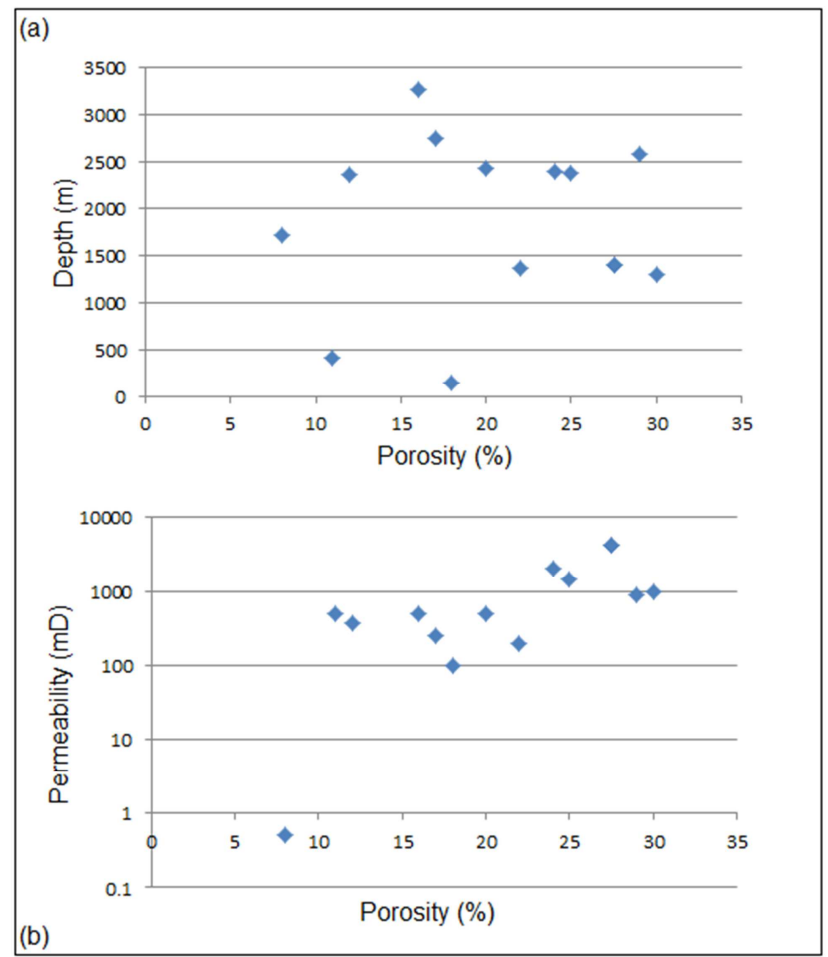

Figure 2. Key data from deltaic reservoirs. 


\subsection{Deltaic Reservoirs}

From thirteen deltaic reservoirs (Table 2), the average porosity is $20.5 \%$. Majority of the reservoirs have porosity between 15 and $30 \%$. There is a correlation between porosity and the depth of reservoirs (Figure 2a). Apart from one reservoir, the top six porosity values are in the depth below $(2500 \mathrm{~m})$. In the three reservoirs with the smallest porosity, one of them (11\%) occurred in the shallowest depth of $410 \mathrm{~m}$. The maximum depth recorded in this environment is $3270 \mathrm{~m}$ while $145 \mathrm{~m}$ is the shallowest depth (Figure 2a). There is a correlation between increasing porosity and decreasing depth but this is not a clear pattern (Figure 2a). However, the reservoir at the highest depth $(3270 \mathrm{~m})$ in this environment has a porosity of $16 \%$ which is lower than the average of $20.5 \%$.
The average permeability for these reservoirs is $1143.2 \mathrm{mD}$. Permeability generally increases with porosity (Figure $2 b$ ). The highest permeability in this environment does not occur with the highest porosity. The average of the amount of hydrocarbon recoverable in these reservoirs is $47.5 \%$. The recoverable generally increases with porosity and permeability (Table 2) and the highest recoverable value of $61 \%$ occurs with the highest porosity of $29 \%$. It is important to point out that a reservoir with a relatively low porosity $(8 \%)$ and permeability $(0.5 \mathrm{mD})$ has as a significant amount of recoverable $(60 \%)$. This is a gas and oil-producing reservoir. This once again confirms that gas reservoirs have the tendency to recover significantly higher hydrocarbon with relatively smaller porosity and permeability when compared to oil reservoir.

Table 3. Details of shallow marine reservoirs.

\begin{tabular}{|c|c|c|c|c|c|}
\hline Field & Basin & Location & Strat Unit & Age & Depositional Environment \\
\hline Troll & & Norway & Viking & U. Ju & Stacked shallow shelf, prograding shoreface \\
\hline Snohvit & & Norway & Sto and Nordmela & U. Ju & $\begin{array}{l}\text { Transgressive coastal plain, inner shelf, tidal } \\
\text { channels }\end{array}$ \\
\hline Draugen & & Norway & Rogn & U. Ju & Shallow marine shelf sand bars \\
\hline Piper & & UK & Piper Ss & U. Ju & Marginal marine shelf \\
\hline $\begin{array}{l}\text { Northern } \\
\text { Niger Delta }\end{array}$ & Niger Delta & Nigeria & Agbada & U. Eo- L. Mio & $\begin{array}{l}\text { Paralic, shoreface, shelf, } \\
\text { barrier bars and channel sands }\end{array}$ \\
\hline Takula & & Cabinda & Vermelha Ss & U. Cr & $\begin{array}{l}\text { Stacked nearshore, coastal sands, foreshore, } \\
\text { tidal channels }\end{array}$ \\
\hline Cueta-Tomporo & & Venezuela & Lagunillas & Eo-Mio & Shallow coastal bars and fluvio-deltaic channels \\
\hline El Furrial & & Venezuela & Naricual Ss & U. Oli & Shallow marine and barrier bars \\
\hline Lagifu/Hedinia & & $\begin{array}{l}\text { Papua New } \\
\text { Guinea }\end{array}$ & Toro Ss & L. $\mathrm{Cr}$ & Stacked regressive barrier bars \\
\hline Fortescue & Southeast & Australia & Latrobe & Eo & $\begin{array}{l}\text { Transgressive coastal plain, coastal plain, } \\
\text { shoreface }\end{array}$ \\
\hline Venture & & Canada & Venture Ss & U. Cr & Shallow marine, deltaic \\
\hline Tom O'Connor & & USA & Frio & Oli & Inner-middle shelf to foreshore, beach \\
\hline Middle Ob & West Siberian & Russia & & L. $\mathrm{Cr}$ & Shallow marine and fluvio-deltaic \\
\hline Cupiagua & & Colombia & Llanos Foothills/ Mirador & Lt. Cr- Lt. Eo & Shallow marine-alluvial \\
\hline Tom Walsh-Owen & Rio Grande Embayment & USA & Olmos & L. $\mathrm{Cr}$ & Marine shelf \\
\hline Thomasville & Mississippi Interior Salt & USA & Smackover & L. Ju & Nearshore-mid ramp \\
\hline Gudao & Zhanhua & China & Guantao & Mio & Lakeshore beaches, fan delta, fluvial channels \\
\hline
\end{tabular}

Table 3. Continued.

\begin{tabular}{|c|c|c|c|c|c|c|c|c|c|}
\hline \multirow{2}{*}{$\begin{array}{l}\text { Depth } \\
\text { (m) }\end{array}$} & \multirow{2}{*}{$\begin{array}{l}\text { Porosity } \\
(\%)\end{array}$} & \multirow{2}{*}{$\begin{array}{l}\text { Permeability } \\
(\mathrm{mD})\end{array}$} & \multirow{2}{*}{$\begin{array}{l}\text { Thickness } \\
\text { of Pay (m) }\end{array}$} & \multirow{2}{*}{$\begin{array}{l}\text { Net/Gross } \\
(\%)\end{array}$} & Area & Type & In Place & Recoverable & References \\
\hline & & & & & \multicolumn{2}{|c|}{$(\mathrm{Sq} \mathrm{Km})$} & \multicolumn{3}{|c|}{ (MMBO/ BCFG) } \\
\hline $1300-1500$ & 25 & $500-10000$ & & & & $\mathrm{O}, \mathrm{G}$ & & $9000 \mathrm{MMBO}$ & Morse [54] \\
\hline $2280-2418$ & $5-15$ & 200 & & & & G & 4.5 & & Morse [54] \\
\hline 1600 & 28 & $700-10000$ & & & & $\mathrm{O}$ & 1100 & $410(37.2 \%)$ & Provan [56] \\
\hline 2195 & 24 & 4000 & & & & $\mathrm{O}$ & & 600 & Maher [43] \\
\hline 1700 & $15-25$ & $1000-2000$ & & & & $\mathrm{O}, \mathrm{G}$ & 4500 & & Morse [54] \\
\hline $971-1038$ & 25 & 1000 & & & & $\mathrm{O}$ & 2100 & & Dale et al. [20] \\
\hline $4510-5180$ & $12-17$ & $10-1200$ & & & & $\mathrm{O}$ & & 1400 & Ramirez and Marcano [58] \\
\hline $3962-4120$ & $11-16$ & & & & & $\mathrm{O}$ & 4500 & $890(19.7 \%)$ & Prieto and Valdes [55] \\
\hline 2438 & 13 & 300 & 90 & & & $\mathrm{O}$ & & 150 & Matkze et al. [46] \\
\hline $2300-2400$ & 20 & $100-10000$ & 130 & & & $\mathrm{O}$ & 420 & $280(66.6 \%)$ & Hendrich et al. [30] \\
\hline $4436-5800$ & 16 & $10-40$ & 130 & & & G & & 250 & Mills [53] \\
\hline $1371-1828$ & 31 & $500-2000$ & 1000 & & & $\mathrm{O}, \mathrm{G}$ & 670 & & Morse [54] \\
\hline $2380-2820$ & $3-25$ & $0.01-300$ & 30 & & & $\mathrm{O}$ & & & James [36] \\
\hline $3953-4590$ & $2-8.1$ & $0.1-90$ & 1800 & & & $\mathrm{O}, \mathrm{G}$ & $1100 / 4.5$ & $550 / 2.25(51 \%)$ & Ramon and Fajardo [59] \\
\hline 2195 & $8-23(15)$ & $0.01-8(0.4)$ & 6.1 & 57 & 90 & G & 228 & $115(51 \%)$ & Snedden and Jumper [64] \\
\hline 6075 & $5-10(7)$ & $0.001-6(0.35)$ & 90 & 43 & 50.3 & G & 600 & & Shew and Garner [63] \\
\hline $1190-1300$ & $30-32$ & $500-2000$ & & & & $\mathrm{O}$ & & 60 & Chen and Wang [15] \\
\hline
\end{tabular}




\subsection{Shallow Marine Reservoirs}

The average porosity from thirteen shallow marine reservoirs (Table 3 ) is $18.7 \%$. There is a correlation between porosity and the depth of reservoirs. Porosity increases with decreasing depth of reservoirs (Figure 3a). However, there are two reservoirs with an exception. These reservoirs with $14.5 \%$ and $16 \%$ porosity below the average porosity $(18.7 \%)$ are located at depths of 4845 and $5118 \mathrm{~m}$ respectively.

Permeability generally increases with porosity although this is not a straight-line relationship (Figure 3b). As in fluvial reservoirs, permeability varies with the same porosity values. In two different reservoirs with $20 \%$ porosity, permeability ranges from 1500 to $5050 \mathrm{mD}$ while permeability also ranges from 1000 to $5250 \mathrm{mD}$ when porosity is $25 \%$ in two other reservoirs (Figure 3b). As in fluvial and deltaic reservoirs, the highest permeability does not occur with the highest porosity. The permeability of $1250 \mathrm{mD}$, which occurs with the highest porosity $(31 \%)$, is less than the average permeability $(1623.9 \mathrm{mD})$ for the shallow marine reservoirs. The maximum depth in this environment is $6075 \mathrm{~m}$ while $1245 \mathrm{~m}$ is the minimum. There is a correlation between increasing porosity and decreasing depth (Figure 3a). The reservoir at the second highest depth $(5118 \mathrm{~m})$ has a porosity of $16 \%$ which is lower than the average of $18.7 \%$.

There are only four data available on the amount of hydrocarbon recoverable in this environment (Table 3). The average amount of hydrocarbon recoverable in these reservoirs is $53.16 \%$. Although the datasets are small, the recoverable generally increases with porosity and permeability. It is however important to point out that a reservoir with the lowest recoverable amount (37.2\%) has the second highest porosity $(28 \%)$ and the maximum permeability $(5350 \mathrm{mD})$. A reservoir with a relatively low porosity $(5.1 \%)$ and permeability $(45.1 \mathrm{mD})$ has as a significant amount of recoverable (51\%) which is very close to the average for this environment. This reservoir produces oil and gas and the amount of total recoverable may have been significantly increased by the amount of gas recoverable.

\subsection{Deep Marine Reservoirs}

From ten deep marine reservoirs (Table 4), the average porosity is $27.4 \%$ which is the highest among all the environments. The maximum porosity of $35 \%$ is the joint highest in all the environments while minimum porosity of $17.5 \%$ is the highest of all the minimum porosity. There is a correlation between porosity and the depth of reservoirs as in other reservoirs. Porosity generally increases with decreasing depth of reservoirs (Figure 4a). The top three porous reservoirs have the shallowest depths. Apart from one reservoir, the amount recoverable in this environment increases with porosity and has a straight-line relationship with porosity (Table 4).

Table 4. Details of deep marine reservoirs.

\begin{tabular}{|c|c|c|c|c|c|}
\hline Field & Basin & Location & Stratigraphic & Age & Depositional Environment \\
\hline Yowlumne & San Joanquin & USA & Stevens Ss & L. Mio & Submarine fan \\
\hline Forties & Central Garben & UK & Forties & U. Pal & Submarine fan \\
\hline Midway-Sunset (Webster Zone) & San Joanquin & USA & Webster Zone & L. Mio & Turbidite \\
\hline Arbuckle & Sacramento & USA & Forbes & L. $\mathrm{Cr}$ & Deep sea fan \\
\hline Alba & North Sea & UK & Alba & Eo & Deep sea fan, channel and levee complex \\
\hline Miller & North Sea & UK & Brae & U. Ju & Submarine fan \\
\hline Marlim & & Brazil & Carapebus Ss & U. Olig & Submarine fan \\
\hline Albacora & & Brazil & & U.Cr-Mio & Submarine fan, lobe and channels \\
\hline Namorado & & Brazil & & U. $\mathrm{Cr}$ & Submarine fan, stacked channels and lobes \\
\hline Marimba & & Brazil & & U. $\mathrm{Cr}$ & Turbidite \\
\hline Willimington & Los Angeles & USA & Puente, Repetto & U. Mio- U. Pli & Turbidite \\
\hline
\end{tabular}

Table 4. Continued.

\begin{tabular}{|c|c|c|c|c|c|c|c|c|c|}
\hline \multirow{2}{*}{$\begin{array}{l}\text { Depth } \\
\text { (m) }\end{array}$} & \multirow{2}{*}{$\begin{array}{l}\text { Porosity } \\
(\%)\end{array}$} & \multirow{2}{*}{$\begin{array}{l}\text { Permeability } \\
(\mathrm{mD})\end{array}$} & \multirow{2}{*}{$\begin{array}{l}\text { Thickness } \\
\text { of Pay (m) }\end{array}$} & \multirow{2}{*}{$\begin{array}{l}\text { Net/Gross } \\
(\%)\end{array}$} & Area & Type & In Place & Recoverable & \multirow{2}{*}{ References } \\
\hline & & & & & \multicolumn{2}{|c|}{$(\mathrm{Sq} \mathrm{Km})$} & \multicolumn{2}{|c|}{ (MMBO/ BCFG) } & \\
\hline $3445-4085$ & $5-23(18)$ & $1-700(100)$ & 46 & 75 & 13.4 & $\mathrm{O}$ & 280 & $78(28 \%)$ & Berg and Royo [9] \\
\hline 2135 & $24-27(26)$ & $500-2000(1000)$ & 120 & $25-100$ & 96 & $\mathrm{O}$ & 4300 & $2500(59 \%)$ & Kulpecz and Van Geuns [40] \\
\hline $210-365$ & $28-35(33)$ & $800-4000(1000)$ & $15-76$ & $60-80$ & 2.9 & $\mathrm{O}$ & & & Hall and Link [27] \\
\hline $1525-1980$ & $20-25(23)$ & & $3-46$ & $50-100$ & 46.6 & G & & 75 & Imperato and Nilsen [35] \\
\hline 1860 & 35 & 2800 & 90 & & & $\mathrm{O}$ & 1100 & & $\begin{array}{l}\text { Mattingly and Bretthauer } \\
\text { [47] }\end{array}$ \\
\hline $3890-4090$ & $12-23$ & $50-1200$ & 60 & & & $\mathrm{O}, \mathrm{G}$ & 670 & 400 MMBO (59.7\%) & McClure and Brown [49] \\
\hline $2500-2700$ & 30 & 1200 & 200 & & & $\mathrm{O}$ & 8200 & & Morse [54] \\
\hline $2350-3260$ & 25 & 1500 & 110 & & & $\mathrm{O}$ & 4000 & & Morse [54] \\
\hline $2980-3080$ & 30 & 1000 & & & & $\mathrm{O}$ & & 250 & Bacoccoli et al. [6] \\
\hline 2700 & 27 & 1700 & & & & $\mathrm{O}$ & 470 & $170(36.1 \%)$ & Horschutz et al. [32] \\
\hline $610-1830$ & $30-35$ & $700-1500$ & $>600$ & & & $\mathrm{O}$ & 9600 & $2500(26 \%)$ & Mayuga [48] \\
\hline
\end{tabular}




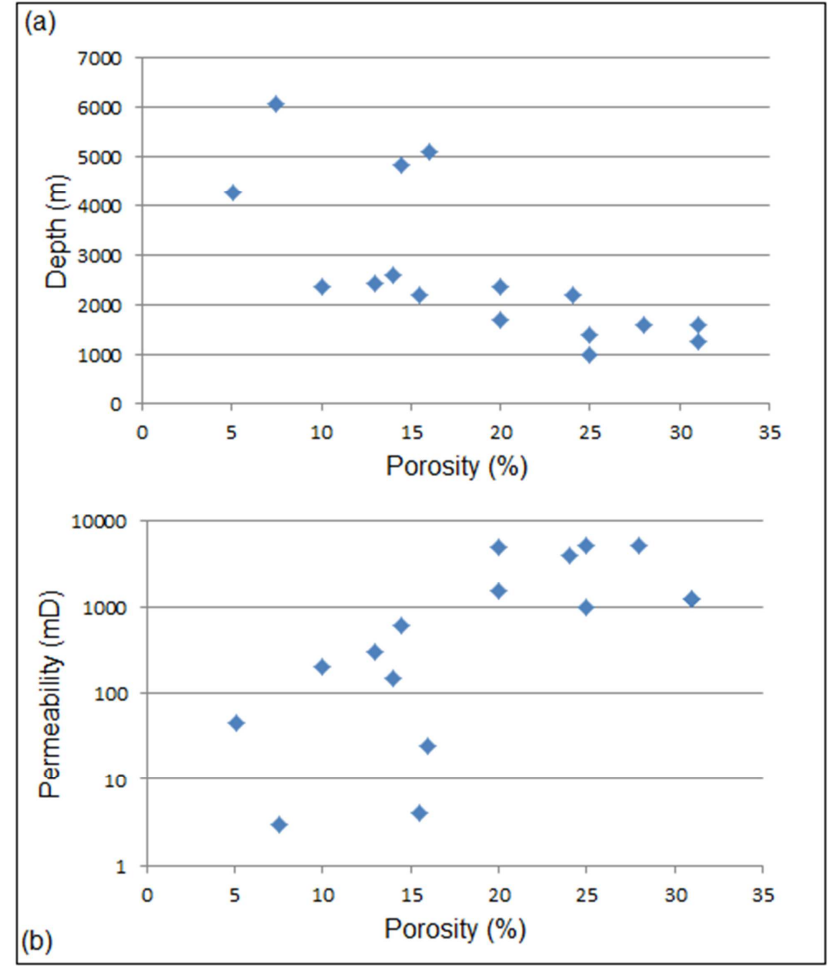

Figure 3. Key data from shallow marine reservoirs.

The average permeability $(1202.5 \mathrm{mD})$ for these reservoirs is the second highest permeability after shallow marine reservoirs among all the environments. Permeability increases with porosity (Figure 4b). Unlike other environments, the highest permeability occurs in the same reservoir with the highest porosity. This may suggest that the porosity in this reservoir is an effective porosity. Unlike other reservoirs, the variability of permeability with the same porosity is not well pronounced.
The maximum depth is $3990 \mathrm{~m}$ while $287.5 \mathrm{~m}$ is the shallowest depth. There is a correlation between increasing porosity and decreasing depth (Figure 4a). The reservoir at the highest depth has a significant amount of recoverable (59.7\%), with $17.5 \%$ porosity and permeability of $625 \mathrm{mD}$. The average amount of hydrocarbon recoverable in these reservoirs is $41.7 \%$. The amount recoverable generally increases with porosity and permeability and decreases with depth (Table 4).

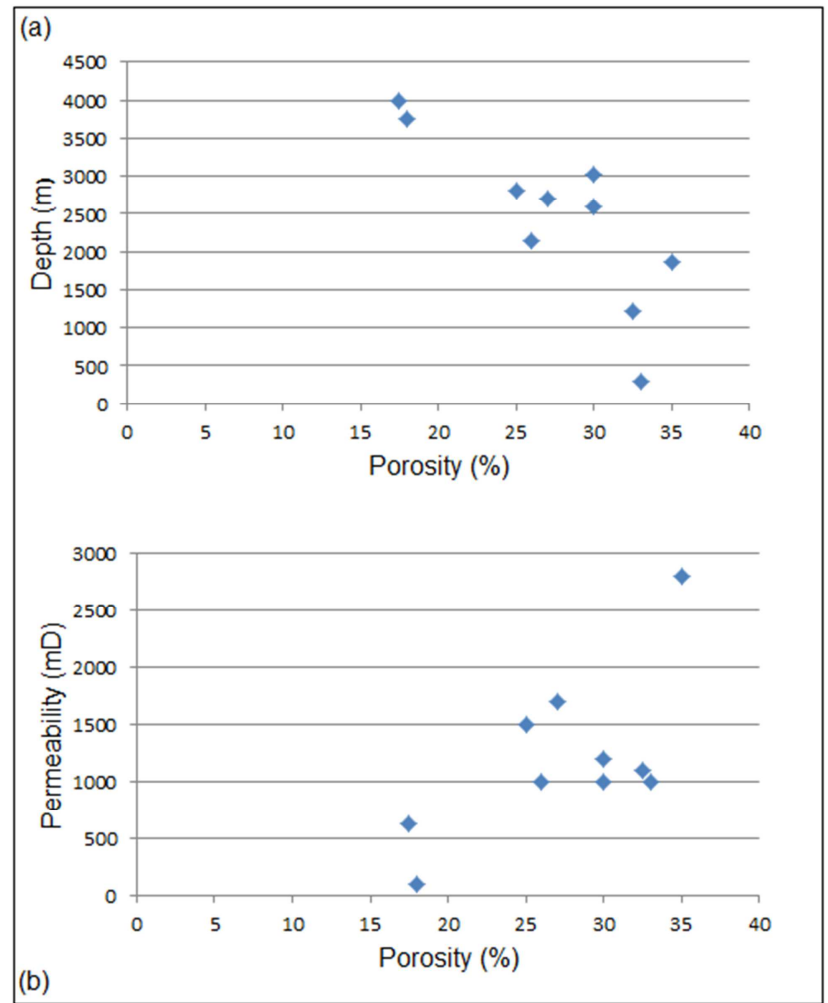

Figure 4. Key data from deep marine reservoirs.

Table 5. Details of Aeolian reservoirs.

\begin{tabular}{llllll}
\hline Field & Basin & Location & Stratigraphic Unit & Age & Depositional Environment \\
\hline Caprock & Permian & USA & Shattuck/ Queen & Per & Aeolian, desert fluvial, and sabkha \\
Pisgah Anticline & Mississippi Interior Salt & USA & Norphlet & L. Ju & Aeolian \\
South State Line & Mississippi Interior Salt & USA & Norphlet & L. Ju & Aeolian \\
Viking & & UK & Leman Ss & L. Per & Aeolian with Sabkha and alluvial beds \\
Urucu & & Brazil & C. Itaituba & & Aeolian \\
Painter & & USA & Nuggest Ss & L. Ju & Aeolian \\
\hline
\end{tabular}

Table 5. Continued.

\begin{tabular}{|c|c|c|c|c|c|c|c|c|c|}
\hline \multirow{2}{*}{$\begin{array}{l}\text { Depth } \\
\text { (m) }\end{array}$} & \multirow{2}{*}{$\begin{array}{l}\text { Porosity } \\
(\%)\end{array}$} & \multirow{2}{*}{$\begin{array}{l}\text { Permeability } \\
(\mathrm{mD})\end{array}$} & \multirow{2}{*}{$\begin{array}{l}\text { Thickness } \\
\text { of Pay (m) }\end{array}$} & \multirow{2}{*}{$\begin{array}{l}\text { Net/Gross } \\
(\%)\end{array}$} & \multirow{2}{*}{\multicolumn{2}{|c|}{$\begin{array}{ll}\text { Area } & \text { Type } \\
\text { (Sq Km) } & \\
\end{array}$}} & \multirow{2}{*}{\multicolumn{2}{|c|}{ (MMBO/ BCFG) }} & \multirow{2}{*}{ References } \\
\hline & & & & & & & & & \\
\hline 945 & $15-30$ & $30-650$ & 3 & 50 & 100 & $\mathrm{O}$ & 290 & $75.5(26 \%)$ & Malicse and Mazzullo [44] \\
\hline $4880-5180$ & $1-24(12)$ & $0.05-1200(1)$ & $151-362$ & 100 & 57.6 & G & 2000 & $1300(65 \%)$ & Studlick et al. [66] \\
\hline 5460 & $1-21(9.5-16.5)$ & $0.1-84(0.6-15.5)$ & 181 & 100 & 6.5 & G & & & Thomson and Stancliffe [69] \\
\hline $2850-2877$ & 14 & $30-80$ & 244 & & & G & & 0.6 & Gage [23] \\
\hline & $10-30$ & $10-1200$ & & & & $\mathrm{O}$ & 70 & & Mello et al. [50] \\
\hline 2918 & 14 & 23 & 260 & & & $\mathrm{O}, \mathrm{G}$ & & $910 \mathrm{MMBO}$ & Lamb [41] \\
\hline
\end{tabular}

\subsection{Aeolian Reservoirs}

From only six aeolian reservoirs (Table 5), the average porosity is $15.9 \%$ and this is the lowest average among the entire depositional environments. The maximum and minimum porosity are $22.5 \%$ and $11 \%$ respectively. The 
minimum porosity of $11 \%$ is higher than the minimum porosity in fluvial and deltaic reservoirs. The porosity increases with depth (Figure 5a). Permeability generally increases with porosity (Figure 5b). The average depth of reservoir is $3443.4 \mathrm{~m}$ and it is the highest among all the environments. The maximum depth recorded in this environment is as high as $5460 \mathrm{~m}$ while $945 \mathrm{~m}$ is the shallowest depth. Since permeability depends on the effective porosity, the depth of burial of the reservoirs may have affected permeability. The reservoir at the maximum depth has porosity of $11 \%$ and permeability of $42 \mathrm{mD}$ that are lower than the average for this environment. The relatively deeper burial depth of these reservoirs may partly explain the lower porosity and permeability. There is a good correlation between increasing porosity and decreasing depth (Figure 5a). Recoverable data are available from only two reservoirs in this environment and these are $65 \%$ and $26 \%$. A significant amount of recoverable $(65 \%)$ is obtainable at relatively high depth of $5030 \mathrm{~m}$.

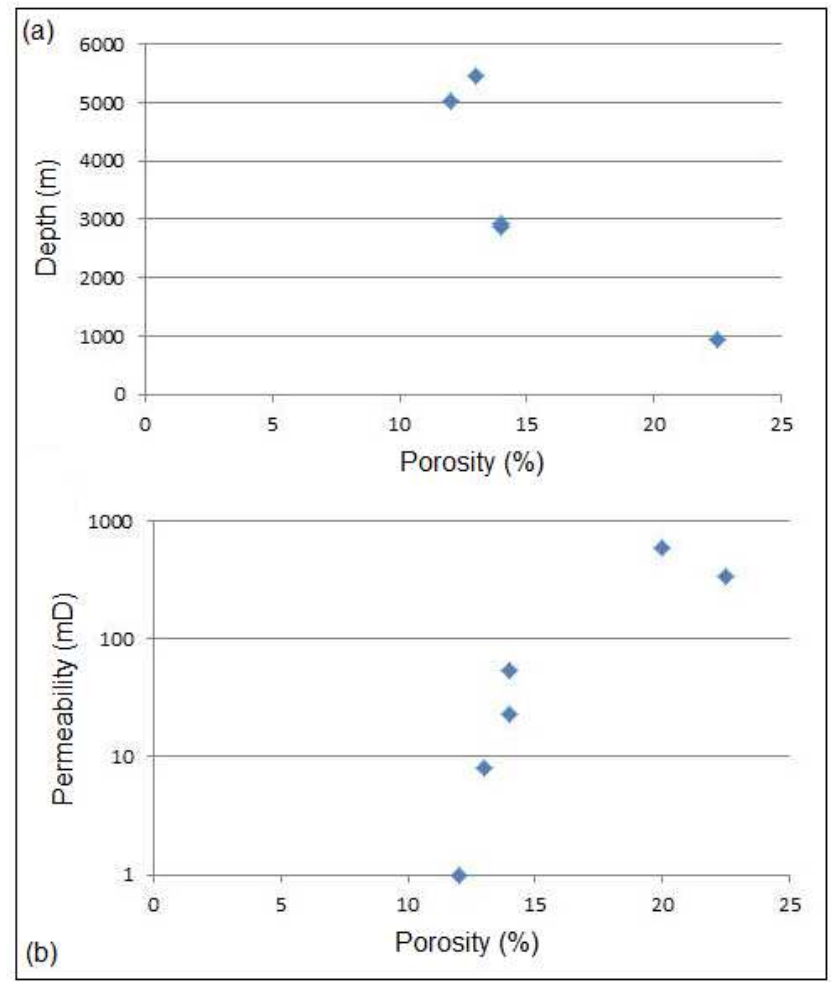

Figure 5. Key data from aeolian reservoirs.

\section{Discussion}

From the available data (Table 6), the average porosity of all the reservoirs is $20.1 \%$. When compared with the averages in the different environments, only the deep marine and deltaic reservoirs have higher porosities (Table 7 ). About $47 \%$ of the reservoirs have porosity above $20 \%$ (Figure $6 \mathrm{a}$ ). As expected, permeability generally increases with porosity (Figure 6a). The average permeability is $1100.6 \mathrm{mD}$. Only the shallow marine, deep marine and deltaic reservoirs have higher permeability than this. About $72 \%$ of the reservoirs have permeability of $1100 \mathrm{mD}$ or less while about $15 \%$ have permeability equal to or greater than $2000 \mathrm{mD}$. It appears that in many reservoirs, once the porosity gets to $20 \%$ and above, the permeability jumps significantly to $4000 \mathrm{mD}$ and above. In some reservoirs once the porosity reaches $35 \%$ and above, the permeability hovers around $1000 \mathrm{mD}$ and beyond. The average depth of reservoirs is $2350.2 \mathrm{~m}$. Aeolian, shallow, and deep marine reservoirs in increasing order have higher depths than this average.

When all these averages (Table 6) are taken into consideration, it is likely that a reservoir with porosity of about $20 \%$ and a permeability of around $1100 \mathrm{mD}$ may recover about $41 \%$ of hydrocarbon in place provided all other necessary factors are favourable. In addition to this, gas reservoirs are likely to recover more than $41 \%$ with porosity of $20 \%$ or less because gas reservoirs generally recover relatively higher hydrocarbon with similar or lower porosity and permeability than oil reservoirs. Permeability varies with same porosity in many reservoirs across all the depositional environments. The implications of this for hydrocarbon exploration may include but not limited to: (1) the variation in the effective porosity of reservoir sandstones with similar total porosity. Significant difference in the connectivity of pores may also account for variation in the permeability of sandstones with similar or same porosity, (2) spatial and temporal variations and heterogeneity at different scales may also cause variation in the permeability when the reservoir sandstones have similar porosity [45, 54, 62].

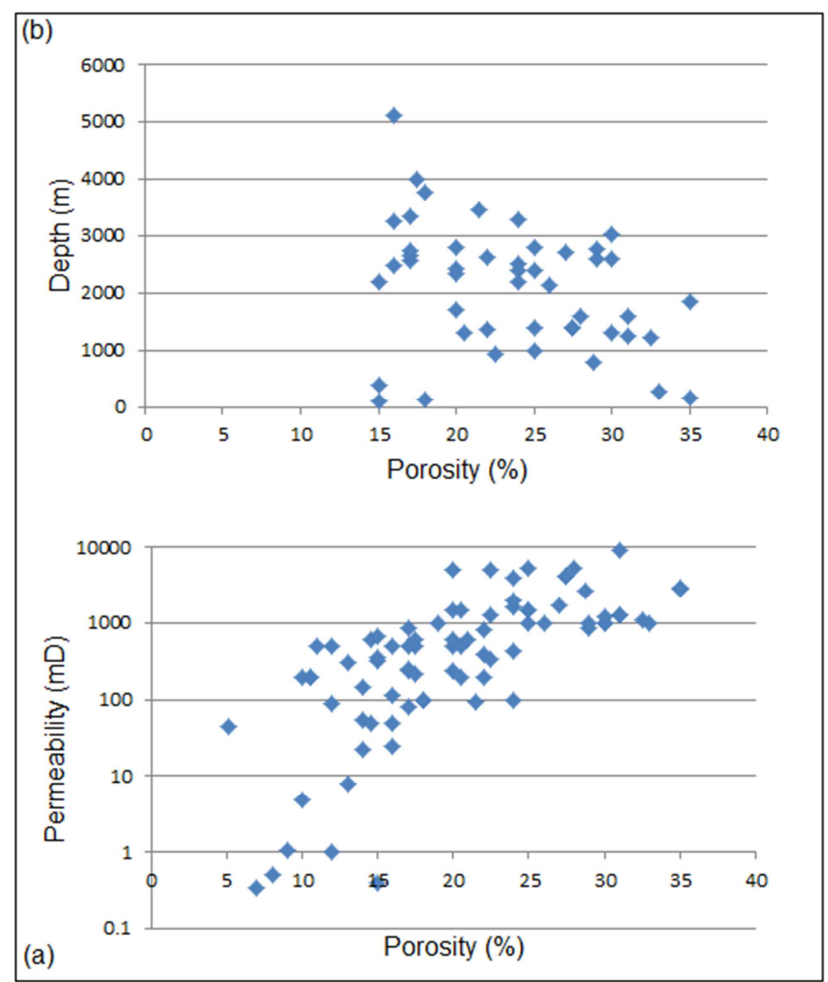

Figure 6. Key data from clastic reservoirs.

Except for secondary porosity, it is generally expected that porosity will decrease with depth in sandstones due to 
diagenesis and other related processes. In the current review, the impact of depth on porosity is clearly evident especially in the aeolian reservoirs (Figure 5a). On the average they have the deepest burial depth and as a result have the lowest porosity and permeability among the reservoirs in all the environments. The deep burial may have resulted in significant reduction in the original porosity of these reservoir sandstones. From the smallest porosity of $5.1 \%$ to below $20 \%$, the depth of reservoirs reaches maximum depth of $6075 \mathrm{~m}$ (Figure 6b). However, once the porosity reaches 20\% and above, the depth of reservoirs dropped to $3450 \mathrm{~m}$. This may suggest that the quality of reservoir porosity may be significantly affected and reduced beyond this depth. However, based on other factors of individual reservoirs, there may be some exceptions to the relationship between depth and porosity described above. However, other factors such as facies, heterogeneity, subsidence, faulting, fracturing, etc will have to be taken into consideration when considering the effect of depth on the porosity and permeability of clastic reservoirs $[45,51,54,62]$.

The average value of the amount recoverable from all the reservoirs is $41.8 \%$. Apart from the fluvial and deep marine reservoirs, the reservoirs in the other environments have higher recoverable than this average (Table 7). There is a correlation between the amount and type of hydrocarbon recoverable. The present data shows that a gas reservoir recovers significantly higher hydrocarbon than an oil reservoir even when the former has lower porosity and permeability. The viscosity of gas may be an important factor responsible for this. The two gas reservoirs with the highest recoverable (81 and $80 \%$ ) have porosity and permeability that are significantly lower than the average of $20 \%$ and $1100 \mathrm{mD}$ respectively. In addition, the minimum recoverable amount for a gas reservoir is $51 \%$ and this was achieved with lower than average porosity and permeability. There is no clear trend with depth of reservoirs and the amount of hydrocarbon recoverable although more than $85 \%$ of the data on recoverable are recorded at depth of $2700 \mathrm{~m}$ or below (Table 6).

Table 6. Key data from clastic reservoirs based on Tables 1-5.

\begin{tabular}{|c|c|c|c|c|}
\hline Type & Porosity (\%) & Permeability (mD) & Depth (m) & Recoverable (\%) \\
\hline Oil \& Gas & 5.1 & 45.1 & 4271.5 & 51 \\
\hline- & 7 & 0.35 & 6075 & - \\
\hline Gas \& Oil & 8 & 0.5 & 1710 & 60 \\
\hline Oil & 9 & 1.05 & - & 18 \\
\hline Oil \& Gas & 10 & 5 & 2195 & 10 \\
\hline- & 10 & 200 & 2349 & - \\
\hline Gas & 10.5 & 200 & - & 81 \\
\hline Oil & 10.5 & 200 & 1750 & 34 \\
\hline- & 11 & 505 & 410 & - \\
\hline Oil & 12 & 500.5 & - & 15 \\
\hline Oil & 12 & 90 & 2367 & 29 \\
\hline Gas & 12 & 1 & 5030 & 65 \\
\hline- & 13 & 8.1 & 5460 & - \\
\hline- & 13 & 300 & 2438 & - \\
\hline- & 14 & 55 & 2864 & - \\
\hline- & 14 & 23 & 2918 & - \\
\hline- & 14 & 150 & 2600 & - \\
\hline Gas & 14.5 & 50.5 & - & 80 \\
\hline - & 14.5 & 605 & 4845 & - \\
\hline Oil & 15 & 315 & - & 25 \\
\hline Oil \& Gas & 15 & 350 & 100 & 23 \\
\hline Oil \& Gas & 15 & 670 & 380 & 33 \\
\hline Gas & 15 & 0.4 & 2195 & 51 \\
\hline - & 16 & 50 & - & - \\
\hline Oil & 16 & 115 & 2470 & 30 \\
\hline- & 16 & 500 & 3270 & - \\
\hline - & 16 & 25 & 5118 & - \\
\hline - & 17 & 80 & 2560 & - \\
\hline - & 17 & 236 & 3350 & - \\
\hline- & 17 & 500 & 2644 & 41.5 \\
\hline Oil \& Gas & 17 & 850 & & - \\
\hline - & 17 & 250 & 2750 & - \\
\hline - & 17.5 & 500 & & - \\
\hline Oil & 17.5 & 217 & & 9.6 \\
\hline Oil \& Gas & 17.5 & 625 & 3990 & 59.7 \\
\hline Oil \& Gas & 18 & 99 & 145 & 30 \\
\hline Oil & 18 & 100 & 3765 & 28 \\
\hline- & 19 & 1000 & & - \\
\hline- & 20 & 240 & 2800 & - \\
\hline
\end{tabular}




\begin{tabular}{|c|c|c|c|c|}
\hline Type & Porosity (\%) & Permeability (mD) & Depth (m) & Recoverable (\%) \\
\hline- & 20 & 500 & 2438 & - \\
\hline - & 20 & 605 & & - \\
\hline - & 20 & 1500 & 1700 & - \\
\hline \multirow[t]{2}{*}{ Oil } & 20 & 5050 & 2350 & 66.6 \\
\hline & 20.5 & 200 & 1320 & \\
\hline Gas & 20.5 & 500.5 & - & 75 \\
\hline Oil & 20.5 & 1500 & - & 42 \\
\hline- & 21 & 625 & - & - \\
\hline - & 21.5 & 92.5 & 3450 & - \\
\hline Oil \& Gas & 22 & 400 & 2620 & 56 \\
\hline- & 22 & 805 & - & - \\
\hline - & 22 & 200 & 1372 & - \\
\hline- & 22.5 & 1255 & - & - \\
\hline Oil \& Gas & 22.5 & 5010 & - & 45.8 \\
\hline Oil & 22.5 & 340 & 945 & 26 \\
\hline Oil & 24 & 100 & 3283 & 67 \\
\hline Oil & 24 & 427.5 & 2526 & 31 \\
\hline Oil & 24 & 1650 & - & 37 \\
\hline Oil \& Gas & 24 & 2000 & 2410 & 51 \\
\hline- & 24 & 4000 & 2195 & - \\
\hline Oil & 25 & 1450 & 2393 & 54 \\
\hline - & 25 & 5250 & 1400 & - \\
\hline - & 25 & 1000 & 1004.5 & - \\
\hline - & 25 & 1500 & 2805 & - \\
\hline Oil & 26 & 1000 & 2135 & 59 \\
\hline Oil & 27 & 1700 & 2700 & 36.1 \\
\hline- & 27.5 & 4125 & 1400 & - \\
\hline Oil & 27.5 & 4125 & 1400 & 37 \\
\hline Oil & 28 & 5350 & 1600 & 37.2 \\
\hline Oil & 28.8 & 2750 & 790 & 7.5 \\
\hline- & 29 & 1000 & 2779 & - \\
\hline Oil & 29 & 875 & 2585 & 61 \\
\hline- & 30 & 1000 & 1300 & - \\
\hline - & 30 & 1000 & 3030 & - \\
\hline - & 30 & 1200 & 2600 & - \\
\hline - & 31 & 9000 & & - \\
\hline - & 31 & 1250 & 1245 & - \\
\hline- & 31 & 1250 & 1599.5 & - \\
\hline Oil & 32.5 & 1100 & 1220 & 26 \\
\hline- & 33 & 1000 & 287.5 & - \\
\hline - & 35 & 3000 & 152 & - \\
\hline- & 35 & 2800 & 1860 & - \\
\hline Average & 20.1 & 1100.6 & 2350.2 & 41.8 \\
\hline Maximum & 35 & 9000 & 6075 & 81 \\
\hline Minimum & 5.1 & 0.35 & 100 & 7.5 \\
\hline $\mathrm{N}$ & 81 & 81 & 62 & 38 \\
\hline
\end{tabular}

Table 7. The summary of key data from clastic reservoirs based on Tables 1-5.

\begin{tabular}{|c|c|c|c|c|c|c|c|c|c|c|c|c|c|c|c|c|}
\hline \multirow{2}{*}{ Environment } & \multicolumn{4}{|c|}{ Porosity (\%) } & \multicolumn{5}{|c|}{ Permeability (mD) } & \multicolumn{4}{|c|}{ Depth (m) } & \multicolumn{3}{|c|}{ Recoverable (\%) } \\
\hline & Ave & Max & Min & $\mathbf{N}$ & Ave & Max & Min & $\mathbf{N}$ & Ave & Max & Min & $\mathbf{N}$ & Ave & Max & Min & $\mathbf{N}$ \\
\hline Aeolian & 15.9 & 22.5 & 12 & 6 & 172 & 605 & 1 & 6 & 3443.4 & 5460 & 945 & 5 & 45.5 & 65 & 26 & 2 \\
\hline Shallow Marine & 18.7 & 31 & 5.1 & 16 & 1623.9 & 5350 & 25 & 16 & 2686.6 & 6075 & 1245 & 16 & 53.2 & 66.6 & 37.2 & 6 \\
\hline Fluvial & 19.4 & 35 & 9 & 35 & 1027 & 9000 & 1.05 & 35 & 2068.8 & 3450 & 100 & 17 & 38.1 & 81 & 10 & 20 \\
\hline Delta & 20.5 & 30 & 8 & 14 & 1143.2 & 4125 & 0.5 & 14 & 1853.6 & 3270 & 145 & 14 & 47.5 & 61 & 30 & 7 \\
\hline Deep Marine & 27.4 & 35 & 17.5 & 10 & 1202.5 & 2800 & 100 & 10 & 2439.3 & 3990 & 287.5 & 9 & 41.7 & 59.7 & 28 & 5 \\
\hline $\begin{array}{l}\text { Clastic Reservoirs } \\
\text { (Average) }\end{array}$ & 20.1 & 35 & 5.1 & 81 & 1100.6 & 9000 & 0.35 & 81 & 2350.2 & 6075 & 100 & 62 & 41.8 & 81 & 7.5 & 38 \\
\hline
\end{tabular}

\section{Conclusions}

Based on a comprehensive review of reservoir data from eighty-one clastic reservoirs across the world, the following conclusions can be made. Porosity and permeability have significant controls on the amount of hydrocarbon recoverable in clastic reservoirs although they may not necessarily 
guarantee the highest possible recoverable. Within a reservoir, the permeability can vary considerably with the same porosity and the highest permeability may not occur with the highest porosity in other reservoirs. A drastic reduction in porosity at depth greater than $3450 \mathrm{~m}$ was observed in all the reservoirs regardless of the depositional environments. Gas reservoirs consistently demonstrate tendency to recover higher amount of hydrocarbon than oil reservoirs even with lower porosity and permeability. It is likely that an oil reservoir with porosity of about $20 \%$ and a permeability of around $1100 \mathrm{mD}$ may recover about $41 \%$ of oil in place provided all other necessary geologic factors are in place. Gas reservoirs are likely to recover more than $41 \%$ even when they have similar or lower porosity and permeability compared to oil reservoirs. The result of this review, though not exhaustive will serve as a useful guide to petroleum geologists and sedimentologists in predicting and understanding the quality of reservoirs in different continental environments.

\section{Acknowledgements}

The data used in this review were sourced during a doctoral research conducted at the University of Brighton, United Kingdom. Many thanks to the reviewers who made constructive comments to improve the final draft.

\section{References}

[1] Akinlotan, O. O., 2015. The Sedimentology of the Ashdown Formation and the Wadhurst Clay Formation, Southeast England. ( $\mathrm{PhD}$ thesis), University of Brighton, United Kingdom.

[2] Akinlotan, O. O., 2016. Porosity and permeability of the English (Lower Cretaceous) sandstones. Proceedings of the Geologists' Association 127, 681-690.

[3] Akinlotan, O. O., Jolly, B. A., Anyiam, O. A., 2018. Hydrocarbon Generation Potentials of Cenozoic Lacustrine Source Rocks: Gulf of Thailand, Southeast Asia. International Journal of Geology and Earth Sciences 4, $35-55$.

[4] Albright, W. A., Turner, W. L., Williamson, K. R., 1980. Ninian field, UK sector, North Sea. In: M. T. Halbouty (Ed.), Giant oil and gas fields of the decade 1968-1978. American Association of Petroleum Geologists Memoir pp. 173-193.

[5] Atkinson, C. D., McGowen, J. H., Bloch, S., Lundell, L. L., Trumbly, P. N., 1990. Braidplain and deltaic reservoir, Prudhoe Bay Field, Alaska. In: J. H. Barwis, J. G. McPherson, J. R. Studlick (Eds.), Sandstone Petroleum Reservoirs: casebooks in earth sciences, pp. 7-29.

[6] Bacoccoli, G., Morales, R. G., Campos, O. A. J., 1980. The Namorado Oil Field: A Major Oil Discovery in the Campos Basin, Brazil. In: M. T. Halbouty (Ed.), Giant oil and gas fields of the decade 1968-1978. American Association of Petroleum Geologists Memoir 30, pp. 328-338.

[7] Balducchi, A., Pommier, G., 1970. Cambrian oil field of Hassi Messaoud, Algeria. In: M. T. Halbouty (Ed.), Geology of giant petroleum fields American Association of Petroleum
Geologists Memoir pp. 477-488.

[8] Barwis, J. H., 1990. Flood-tidal delta reservoirs, MedoraDickson Trend, North Darkota. In: J. H. Barwis, J. G. McPherson, J. R. Studlick (Eds.), Sandstone Petroleum Reservoirs: casebooks in earth sciences. Springer Verlag, New York, pp. 389-412.

[9] Berg, R. B., Royo, G. R., 1990. Channel-fill turbidite reservoir, Yowlumen Field, California. In: J. H. Barwis, J. G. McPherson, J. R. Studlick (Eds.), Sandstone Petroleum Reservoirs: casebooks in earth sciences. Springer Verlag, New York, pp. 467-487.

[10] Biswas, S. K., Rangaraju, M. K., Thomas, J., Bhattacharya, S. K., 1994. Cambay-Hazad (!) Petroleum System in the South Cambay Basin, India. In: L. B. Magoon, W. G. Dow (Eds.), The Petroleum System--From Source to Trap. American Association of Petroleum Geologists Memoir 60, pp. 615-624.

[11] Bloch, S., 1991. Empirical Prediction of Porosity and Permeability in Sandstones (1). American Association of Petroleum Geologists Bulletin 75, 1145-1160.

[12] Bloch, S., Lander, R. H., Bonnell, L., 2002a. Anomalously high porosity and permeability in deeply buried sandstone reservoirs: Origin and predictability. AAPG bulletin 86, 301-328.

[13] Bloch, S., Lander, R. H., Bonnell, L., 2002b. Anomalously high porosity and permeability in deeply buried sandstone reservoirs: Origin and predictability. American Association of Petroleum Geologists Bulletin 86, 301-328.

[14] Bushell, T. P., 1986. Reservoir Geology of the Morecambe Field. In: J. Brooks, J. Goff, B. Van Hoorne (Eds.), Habitat of Palaeozoic Gas in N. W. Europe. Geological Society, London, Special Publications, pp. 189-208.

[15] Chen, S., Wang, P., 1980. Geology of Gudao Oil Field and Surrounding Areas. In: M. T. Halbouty (Ed.), Giant oil and gas fields of the decade 1968-1978. American Association of Petroleum Geologists Memoir 30, pp. 471-486.

[16] Clark, J. E., Reinson, G. E., 1990. Continuity and performance of an estuarine reservoir, Crystal Field, Alberta, Canada. In: J. H. Barwis, J. G. McPherson, J. R. Studlick (Eds.), Sandstone Petroleum Reservoirs: casebooks in earth sciences. Springer Verlag, New York, pp. 343-361.

[17] Cleveland, M. N., Molina, J., 1990. Deltaic reservoirs of the Cano Limon Field, Colombia, South America. In: J. H. Barwis, J. G. McPherson, J. R. Studlick (Eds.), Sandstone Petroleum Reservoirs: casebooks in earth sciences. Springer Verlag, New York, pp. 281-315.

[18] Clifford, H. J., Grund, R., Musrati, H., 1980. Geology of a stratigraphic giant: Messla oil field, Libya. In: Giant oil and gas fields of the decade 1968-1978. In: M. T. Halbouty (Ed.). American Association of Petroleum Geologists Memoir 30 pp. 507-524.

[19] Cooke-Yarborough, P., 1991. The Hewett Field, Blocks 48/28-29-30, 52/4a-5a, UK North Sea. Geological Society, London, Memoirs 14, 433-441.

[20] Dale, C. T., Lopes, J. R., Abilio, S., 1992. Takula oil field and the greater Takula area, Cabinda Angola. In: M. T. Halbouty (Ed.), Giant oil and gas fields of the decade 1978-1988. American Association of Petroleum Geologists Memoir 54, pp. 197-215. 
[21] Dutton, S. P., Loucks, R. G., 2010. Diagenetic controls on evolution of porosity and permeability in lower Tertiary Wilcox sandstones from shallow to ultradeep (200-6700 m) burial, Gulf of Mexico Basin, U.S.A. Marine and Petroleum Geology $27,69-81$.

[22] Ehrenberg, S. N., Gjerstad, H. M., Hadler-Jacobson, F., 1992. Smorbukk field, a gas condensate fault trap in the Haltenbanken Province offshore mid-Norway. In: M. T. Halbouty (Ed.), Giant oil and gas fields of the decade 1978-1988. American Association of Petroleum Geologists Memoir 54, pp. 323-348.

[23] Gage, M., 1980. A Review of the Viking Gas Field. In: M. T. Halbouty (Ed.), Giant oil and gas fields of the decade 1968-1978. American Association of Petroleum Geologists Memoir 30, pp. 39-57.

[24] Gardiner, S., Thomas, D. V., Bowering, E. D., McMinn, L. S., 1990. A braided fluvial reservoir, Peco Field, Alberta, Canada. In: J. H. Barwis, J. G. McPherson, J. R. Studlick (Eds.), Sandstone Petroleum Reservoirs: casebooks in earth sciences. Springer Verlag, New York, pp. 31-56.

[25] Gluyas, J., Swarbrick, R., 2003. Petroleum Geoscience. Blackwell Publishing, Oxford, 359 pp.

[26] Hagen, J., Kvalheim, B., 1992. Oseberg Field. In: M. T. Halbouty (Ed.), Giant oil and gas fields of the decade 1978-1988. American Association of Petroleum Geologists Memoir 54, pp. 417-428.

[27] Hall, B. R., Link, M. H., 1990. Reservoir description of a Miocene turbidite sandstone, Midway-Sunset Field, California. In: J. H. Barwis, J. G. McPherson, J. R. Studlick (Eds.), Sandstone Petroleum Reservoirs: casebooks in earth sciences. Springer Verlag, New York, pp. 509-533.

[28] Harris, N. B., 1989. Reservoir geology of fangst group (middle Jurassic), Heidrun field, offshore mid-Norway. American Association of Petroleum Geologists Bulletin 73, 1415-1435.

[29] Hastings, J. O., 1990. Coarse grained meander belt reservoirs, Rocky Ridge Field, North Dakota. In: J. H. Barwis, J. G. McPherson, J. R. Studlick (Eds.), Sandstone Petroleum Reservoirs: casebooks in earth sciences. Springer Verlag, New York, pp. 57-84.

[30] Hendrich, J. H., Palmer, I. D., Schwebel, D. A., 1992. Fortescue Field, Gippsland Basin, Offshore Australia: Flank Potential Realized, Giant oil and gas fields of the decade 1978-1988. American Association of Petroleum Geologists Memoir 54, pp. 483-492.

[31] Holland, D. S., Nunan, W. E., Lammlein, D. R., Woodhams, R. L., 1980. Eugene Island Block 330 field, offshore Louisiana. In: M. T. Halbouty (Ed.), Giant oil and gas fields of the decade 1968-1978. American Association of Petroleum Geologists Memoir 30, pp. 253-280.

[32] Horschutz, P. M. C., de Freitas, L. C. S., Stank, C. V., da Silva Barrosos, A., a Cruz, W. M., 1992. The Linguado, Carapeba, Vermelho, and Marimba Giant Oil Fields, Campos Basin, Offshore Brazil. In: M. T. Halbouty (Ed.), Giant oil and gas fields of the decade 1978-1988. American Association of Petroleum Geologists Memoir 54, pp. 137-153.

[33] Howard, R. H., Whitaker, S. T., 1990. Fluvial-estuarine valley fill at the Mississippian-Pennsylvanian unconformity, Main Consolidated Field, Illinois. In: J. H. Barwis, J. G. McPherson, J. R. Studlick (Eds.), Sandstone Petroleum Reservoirs: casebooks in earth sciences. Springer Verlag, New York, pp. 319-341.

[34] Huurdeman, A., Breunese, J., Al-Asbahi, A., Lutgert, J., Floris, F., 1991. Assessment of halite-cemented reservoir zones. Journal of Petroleum Technology 43, 518-523.

[35] Imperato, D. P., Nilsen, T. H., 1990. Deep-sea fan channel-levee Complexes, Arbuckle Field, Sacramento Basin, California. In: J. H. Barwis, J. G. McPherson, J. R. Studlick (Eds.), Sandstone Petroleum Reservoirs: casebooks in earth sciences. Springer Verlag, New York, pp. 535-555.

[36] James, R. A., 1996. Causes of permeability variation in a Lower Cretaceous reservoir unit in the West Siberian Basin, Russia. Marine and Petroleum Geology 13, 393-406.

[37] Keltch, B. W., Wilson, D. A., Potter, P. E., 1990. Deltaic depositional controls on Clinton sandstone reservoirs, Senecaville Gas Field, Guernsey County, Ohio. In: J. H. Barwis, J. G. McPherson, J. R. Studlick (Eds.), Sandstone Petroleum Reservoirs: casebooks in earth sciences. Springer Verlag, New York, Springer Verlag, New York, pp. 263-280.

[38] Ketter, F. J., 1991. The Esmond, Forbes and Gordon Fields, Blocks 43/8a, 43/13a, 43/15a, 43/20a, UK North Sea. Geological Society, London, Memoirs 14, 425-432.

[39] Kirk, R. H., 1980. Statford field-a Nort Sea giant. In: M. T. Halbouty (Ed.), Giant oil and gas fields of the decade 1968-1978. American Association of Petroleum Geologists Memoir 30, pp. 95-116.

[40] Kulpecz, A. A., Van Geuns, L. C., 1990. Geological modeling of a turbidite reservoir, Forties Field, North Sea. In: J. H. Barwis, J. G. McPherson, J. R. Studlick (Eds.), Sandstone Petroleum Reservoirs: casebooks in earth sciences. Springer Verlag, New York, pp. 489-507.

[41] Lamb, C. F., 1980. Painter Reservoir Field-Giant in the Wyoming Thrust Belt. In: M. T. Halbouty (Ed.), Giant oil and gas fields of the decade 1968-1978. American Association of Petroleum Geologists Memoir 30, pp. 281-288.

[42] Lelek, J. J., Shepherd, D. B., Stone, D. M., Abdine, A. S., 1992 October field, the latest giant under development in Egypt's Gulf of Suez. In: M. T. Halbouty (Ed.), Giant oil and gas fields of the decade 1978-1988. American Association of Petroleum Geologists Memoir pp. 231-249.

[43] Maher, C. E., 1980. Piper oil field. In: M. T. Halbouty (Ed.), Giant oil and gas fields of the decade 1968-1978. American Association of Petroleum Geologists Memoir 30, pp. 131-172.

[44] Malicse, A., Mazzullo, J., 1990. Reservoir properties of the desert Shattuck Member, Caprock Field, New Mexico. In: J. H. Barwis, J. G. McPherson, J. R. Studlick (Eds.), Sandstone Petroleum Reservoirs: casebooks in earth sciences. Springer Verlag, New York, pp. 133-152.

[45] Martin, J. H., 1993. A review of braided fluvial hydrocarbon reservoirs: the petroleum engineer's perspective. In: J. L. Best, C. S. Bristow (Eds.), Braided Rivers. Geological Society, London, Special Publications, pp. 333-367.

[46] Matkze, R. H., Smith, G. J., Foo, W. K., 1992. Lagifu/Hedinia oil field first oil from the Papuan fold and thrust belt. In: M. T. Halbouty (Ed.), Giant oil and gas fields of the decade 1978-1988. American Association of Petroleum Geologists Memoir 54, pp. 471-482. 
[47] Mattingly, G. A., Bretthauer, H. H., 1992. The Alba Field: A Middle Eocene Deep Water Channel System in the UK North Sea. In: M. T. Halbouty (Ed.), Giant oil and gas fields of the decade 1978-1988. American Association of Petroleum Geologists Memoir 54, pp. 297-305.

[48] Mayuga, M. N., 1970. Geology and Development of California's Giant-Wilmington Oil Field. In: M. T. Halbouty (Ed.), Geology of giant petroleum fields American Association of Petroleum Geologists Memoir 14, pp. 158-184.

[49] McClure, N. M., Brown, A. A., 1992. Miller Field: A Subtle Upper Jurassic Submarine Fan Trap in the South Viking Graben, United Kingdom Sector, North Sea. In: M. T. Halbouty (Ed.), Giant oil and gas fields of the decade 1978-1988. American Association of Petroleum Geologists Memoir 54, pp. 307-322.

[50] Mello, M. R., Koutsoukos, E. A. M., Mohriak, W. U., Bacoccoli, G., 1994. Selected Petroleum Systems in Brazil. In: L. B. Magoon, W. G. Dow (Eds.), The Petroleum System--From Source to Trap. American Association of Petroleum Geologists Memoir 60, pp. 499-512.

[51] Miall, A. D., 1996. The geology of fluvial deposits. Springer, Berlin, 575 pp.

[52] Miller, D. D., McPherson, J. G., Covington, T. E., 1990. Fluviodeltaic reservoir, South Belridge Field, San Joaquin Valley, California. In: J. H. Barwis, J. G. McPherson, J. R. Studlick (Eds.), Sandstone Petroleum Reservoirs: casebooks in earth sciences. Springer Verlag, New York, pp. 109-130.

[53] Mills, H. G., 1970. Geology of Tom O'Connor Field, Refugio County, Texas. In: M. T. Halbouty (Ed.), Geology of giant petroleum fields American Association of Petroleum Geologists Memoir 14, pp. 292-300.

[54] Morse, D. G., 1994. Siliciclastic reservoir rocks. In: L. B. Magoon, W. G. Dow (Eds.), The Petroleum System--From Source to Trap. American Association of Petroleum Geologists Memoir 60, pp. 121-139.

[55] Prieto, R., Valdes, G., 1992. El Furrial oil field a new giant field in an old basin. In: M. T. Halbouty (Ed.), Giant oil and gas fields of the decade 1978-1988. American Association of Petroleum Geologists Memoir 54, pp. 155-161.

[56] Provan, D. M. J., 1992. Draugen oil field, Haltenbanken Province, offshore Norway. In: M. T. Halbouty (Ed.), Giant oil and gas fields of the decade 1978-1988. American Association of Petroleum Geologists Memoir 54, pp. 371-382.

[57] Providence, 2013. The Barryroe Oil Field. http://www.providenceresources.com/sel\%201-11.aspx. (Accessed: 29/10/2013).

[58] Ramirez, E., Marcano, F., 1992. Ceuta-Tomoporo field, Venezuela. In: M. T. Halbouty (Ed.), Giant oil and gas fields of the decade 1978-1988. American Association of Petroleum Geologists Memoir 54, pp. 163-173.

[59] Ramon, J. C., Fajardo, A., 2006. Sedimentology, sequence stratigraphy and reservoir architecture of the Eocene Mirador Formation, Cupiagua field, Llanos Foothills, Columbia. In: P. M. Harris, L. J. Weber (Eds.), Giant hydrocarbon reservoirs of the world: from rocks to reservoir characterisation and modelling. American Association of Petroleum Geologists Memoir 88/SEPM Special Publication, pp. 433-469.

[60] Ritchie, J. S., Pratsides, P., The Carster Fields, Block 44/23a UK North Sea. In: J. R. Parker (Ed.), Petroleum Geology of
NW Europe: Proceedings of the 4th Conference. 1993, Geological Society, pp. 759-770.

[61] Scotman, I. C., Johnes, L. H., 1990. Wave-dominated deltaic reservoirs of the Brent Group, Northwest Hutton Field. In: J. H. Barwis, J. G. McPherson, J. R. Studlick (Eds.), Sandstone Petroleum Reservoirs: casebooks in earth sciences. Springer Verlag, New York, pp. 227-261.

[62] Selley, R. C., 1996. Ancient sedimentary environments and their sub-surface diagnosis. Psychology Press.

[63] Shew, R. D., Garner, M. M., 1990. Reservoir characteristics of nearshore and shelf sandstones in the Jurassic Smackover Formation, Thomasville Field, Mississippi. In: J. H. Barwis, J. G. McPherson, J. R. Studlick (Eds.), Sandstone Petroleum Reservoirs: casebooks in earth sciences. Springer Verlag, New York, pp. 437-464.

[64] Snedden, J. W., Jumper, R. S., 1990. Shelf and shoreface reservoirs, Tom Walsh-Owen Field, Texas. In: J. H. Barwis, J. G. McPherson, J. R. Studlick (Eds.), Sandstone Petroleum Reservoirs: casebooks in earth sciences. Springer Verlag, New York, pp. 415-436.

[65] Strohmenger, C. J., Patterson, P. E., Al-Sahlan, Mitchell, J. C., Feldman, H. R., Demko, T. M., Wellner, R. W., Lehmann, P. J., McCrimmon, G. G., Broomhall, R. W., Al-Ajmi, N., 2006. Sequence stratigraphy and reservoir architecture of Burgan and Bauddud Formations (Lower Cretaceous), Kuwait. In: P. M. Harris, L. J. Weber (Eds.), Giant hydrocarbon reservoirs of the world: from rocks to reservoir characterisation and modelling. American Association of Petroleum Geologists Memoir 88/SEPM Special Publication, pp. 213-245.

[66] Studlick, J. R. J., Shew, R. D., Basye, G. L., Ray, J. R., 1990. A giant carbon dioxide accumulation in the Norphlet Formation, Pisgah Anticline, Mississippi. In: J. H. Barwis, J. G. McPherson, J. R. Studlick (Eds.), Sandstone Petroleum Reservoirs: casebooks in earth sciences. Springer Verlag, New York, pp. 181-204.

[67] Sun, S., Shu, L., Zeng, Y., Cao, J., Feng, Z., 2007. Porositypermeability and textural heterogeneity of reservoir sandstones from the Lower Cretaceous Putaohua Member Of Yaojia Formation, Weixing Oilfield, Songliao Basin, Northeast China. Marine and Petroleum Geology 24, 109-127.

[68] Talukdar, S. C., Marcano, F., 1994. Petroleum Systems of the Maracaibo Basin, Venezuela. In: L. B. Magoon, W. G. Dow (Eds.), The Petroleum System--From Source to Trap. American Association of Petroleum Geologists Memoir 60, pp. 463-481.

[69] Thomson, A., Stancliffe, R. J., 1990. Diagenetic controls on reservoir quality, Eolian Norphlet Formation, South State Line Field Mississippi. In: J. H. Barwis, J. G. McPherson, J. R. Studlick (Eds.), Sandstone Petroleum Reservoirs: casebooks in earth sciences. Springer Verlag, New York, pp. 205-224.

[70] Werren, E. G., Shew, R. D., Adams, E. R., Stancliffe, R. J., 1990. Meander-belt reservoir geology, mid-dip Tuscaloosa, Little Creek Field, Mississippi. In: J. H. Barwis, J. G. McPherson, J. R. Studlick (Eds.), Sandstone Petroleum Reservoirs: casebooks in earth sciences. Springer Verlag, New York, pp. 85-107.

[71] Zaitlin, B. A., Shultz, B. C., 1990. Wave-influenced estuarine sand body, Senlac Heavy Oil Pool, Saskatchewan, Canada. In: J. H. Barwis, J. G. McPherson, J. R. Studlick (Eds.), Sandstone Petroleum Reservoirs: casebooks in earth sciences. Springer Verlag, New York, pp. 363-387. 